\title{
FEEDING PROGRAMS COULD IMPROVE GROWTH PERFORMANCE AND PHYSIOLOGICAL STATUS OF GROWING NEW ZEALAND WHITE RABBITS DURING HOT SUMMER SEASON OF EGYPT.
}

\author{
Mohamed Farghly ; Soliman I. Peris ${ }^{2 *}$; Nahla A. El.razik ${ }^{3}$ Hatem \\ Hamdon $^{4}$; Enas, A.M. Ahmad ${ }^{5}$ and Mohsen Farghaly ${ }^{6}$ \\ ${ }^{1}$ Poultry Production Department, Faculty of Agriculture, Assiut University, Egypt. \\ ${ }^{2}$ Animal Production Department, Faculty of Agriculture, Zagazig University, Egypt. \\ ${ }^{3}$ Animal Production Research Institute, Agric. Research Center, Giza, Egypt. \\ ${ }^{4}$ Animal Production Department, Faculty of Agriculture, New Valley University, Egypt. \\ ${ }^{5}$ Department of Animal and Poultry Production, Faculty of Agriculture, Beni-Suef \\ Univ., Egypt. \\ ${ }^{6}$ Animal Production Department, Faculty of Agriculture, Assiut University, Egypt. \\ *Correspondence: Soliman_peris@ hotmail.com
}

\begin{abstract}
Effects of feeding
night; the fifth one (T4) was fed 100\% program (times and quantities) on of diet at the night.

some growth performance, blood biochemistry, carcass traits and behavioral patterns of male New Zealand White rabbits (NZW) during summer season were investigated. Weaned NZW rabbits (80 bucks) were similarly randomly $(735 \pm 4.7 \mathrm{~g})$ assigned into five experimental groups. Rabbits of the first group were fed ad libitum (control; $C$ ). The second group (T1) was fed $75 \%$ of diet at the morning and $25 \%$ of diet at the night (7 PM); the third group (T2) was fed $50 \%$ of diet at the morning and $50 \%$ of diet at the night; the fourth group (T3) was fed $25 \%$ of diet at the morning and $75 \%$ of diet at the

Rabbits of T3 group showed the heaviest body weight and body weight gain and the best feed conversion ratio during 14-16 weeks of age. Groups of T3 and T4 showed the highest percentage of dressed carcass and the lowest abdominal fat. Rabbits of T3 had the lowest activity of alanine aminotransferase (AST), the lowest value of rectal temperature and the highest glucose concentration.

Conclusively, feeding during the night was preferable in rabbit farms due to its useful impacts on growth, under heat stress of summer months of Egypt.

Keywords: Rabbit, feeding program; heat stress; growth; blood
\end{abstract}

\section{INTRODUCTION}

Heat stress affects negatively growth rate, feed conversion ratio (FCR) and blood parameters (Abdel-Monem et al. , 2007; Daader et al. , 2016; Hassan et al., 
2016; Szendrő et al., 2018; Ferraz et al., 2019; Farghly et al., 2020; Awad et al., 2021). The optimal range of temperature and relative humidity for keeping rabbits is $15-25^{\circ} \mathrm{C}$, and 60-65 \%, respectively (Abdel-Monem et al., 2009). Several attempts were carried out to alleviate the deleterious effects of heat stress (Jimoh and Ewuola, 2016 \& 2018; Farghly et al., 2020; Awad et al., 2021).

Feeding programs (times and quantities) during the day has attracted several investigators (Bergaoui et al., 2008; Gidenne et al., 2012; Sena et al., 2015, Peris and Abd El-Latif, 2021) in attempts to ameliorate the deleterious impacts of heat stress and to improve the biological execution. Rabbits prefer to feed nocturnally and consume $60-70 \%$ of the feed at night (Abdel-Monem et al. 2007 and 2009). To control feed consumption (FC) during growth, the most careful strategy is to give a determined volume of diet a day, which could be given at once or as several meals (Gidenne et al., 2012). There are 3 peak periods (03:00-06:00, 15:00-18:00 and 18:21 h) of feed consumption in rabbits; (Ogbu et al., 2014). Recent studies, Abou-Kassem et al., (2021) and Peris and Abd El-Latif (2021) found that the feed restriction system improved feed utilization by giving the best values of FCR in growing rabbits.

Influence of different feeding times and quantities on the growth performance and the physiological status of growing rabbits during a day under heat stress are not well investigated.

Therefore, the current investigation was carried out to examine the potential of improving the growth performance and the physiological status of growing NZW rabbits under the high temperature of summer conditions by utilizing different feeding programs (times and quantities) during a day in summer season.

\section{MATERIALS AND METHODS}

The present study was implemented at the Rabbitry Farm, Faculty of Agriculture, Assiut University, Egypt.

\section{Rabbits and experimental design}

Eighty bucks of weaned NZW rabbits (average of body weight; $735 \pm 4.7$ g), 6 weeks of age, were randomly assigned into five groups (16 rabbit per each group) in a completely randomized design experiment during summer months (June-August).

The first group was fed ad libitum (control; C). The second group $\left(\mathrm{T}_{1}\right)$ was fed a program (75\% of diet at the morning and $25 \%$ of diet at the night ,7 $\mathrm{PM})$; the third group $\left(\mathrm{T}_{2}\right)$ was fed a program $(50 \%$ of diet at the morning and $50 \%$ of diet at the night); the fourth group $\left(\mathrm{T}_{3}\right)$ was fed a program $(25 \%$ of diet 
at the morning and $75 \%$ of diet at the night); the fifth one $\left(\mathrm{T}_{4}\right)$ was fed a program (100\% of diet at the night).

Rabbits (80 bucks) were kept in wire galvanized cages $(50 \mathrm{~L} \times 55 \mathrm{~W} \times 40 \mathrm{H}$ $\mathrm{cm}$ ), which were provided with manual feeders and automatic nipple drinkers. Rabbits were fed a pelleted basal diet contained $2670 \mathrm{ME} / \mathrm{kcal}, 18.25 \% \mathrm{CP}$ and $11.17 \%$ CF (NRC 1994). All rabbits were raised in a semi-closed house and subjected to the same managerial, hygienic and environmental conditions. Intensity of light was recorded (25-30 lux) through incandescent bulbs. Ambient temperature $\left(\mathrm{C}^{0}\right)$ and relative humidity $(\%)$ were recorded and temperature-humidity index (THI) was calculated (Table 1) according to Marai et al. (2001) as follows:

$$
\mathrm{THI}=\mathrm{db} \mathrm{C}^{\mathrm{o}}-\left\{(0.31-0.31 \mathrm{RH})\left(\mathrm{db} \mathrm{C}^{\mathrm{o}}-14\right)\right\},
$$

Where $\mathrm{db} \mathrm{C}^{\mathrm{O}}$ represents dry bulb temperature in Celsius and $\mathrm{RH}=$ Relative humidity \%., values of THI were classified as follows; $<22.2=$ Absence of heat stress, 22.2 to $<23.2=$ Moderate heat stress, 23.3 to $<25.5=$ Severe heat stress, and $\geq 25.5=$ Very severe heat stress.

Table 1. Means of indoor temperature and humidity values of semi-closed system house

\begin{tabular}{cccccccccc}
\hline \multirow{2}{*}{ Months } & \multicolumn{3}{c}{ Temperature $\left[\mathbf{C}^{\circ}\right]$} & \multicolumn{3}{c}{ Humidity [\%] } & \multicolumn{3}{c}{ THI } \\
\cline { 2 - 10 } & Max. & Min & Av. & Max. & Min. & Av. & Max. & Min. & Av. \\
\hline June & 33.88 & 24.64 & 29.26 & 59.85 & 42.23 & 51.04 & 31.46 & 22.81 & 27.00 \\
Julie & 35.00 & 27.11 & 31.06 & 62.00 & 44.52 & 53.26 & 32.57 & 24.92 & 28.64 \\
August & 35.92 & 26.86 & 31.39 & 61.22 & 43.00 & 52.11 & 33.33 & 24.66 & 28.87 \\
\hline Overall mean & $\mathbf{3 4 . 9 3}$ & $\mathbf{2 6 . 2 0}$ & $\mathbf{3 0 . 5 7}$ & $\mathbf{6 1 . 0 2}$ & $\mathbf{4 3 . 2 5}$ & $\mathbf{5 2 . 1 4}$ & $\mathbf{3 2 . 4 5}$ & $\mathbf{2 4 . 1 3}$ & $\mathbf{2 8 . 1 7}$ \\
\hline Max.= Maximum, Min.= Minimum and Av.= Average & & & &
\end{tabular}

\section{Studied parameters}

Body weight (BW) and FC of each rabbit were measured at 6 weeks of the age, and bi-weekly up to 16 weeks. Body weight gain (BWG) and FCR (g feed/ g gain) were obtained bi-weekly. Rectal temperature $\left(\mathrm{C}^{\circ}\right)$ was recorded, on a weekly basis at $1400 \mathrm{~h}$. At 16 weeks of age, 5 animals per group were randomly chosen and slaughtered (Nofal et al., 1995). Dressed carcass weight and weights of edible parts (liver, heart and kidneys) were recorded. Dressing output as a percentage was obtained by dividing the dressed carcass weight by pre-slaughter weight. Blood samples were collected during slaughter. Plasma total protein, albumin, cholesterol, total lipids and glucose and Aspartate aminotransferase (AST) and Alanine aminotransferase (ALT) activities were measured using kits (Peris and Abd El-Latif, 2021). Globulin was obtained by subtracting and albumin: globulin ratio was calculated. Mortality and morbidity were recorded daily. Health risk was considered as the total of morbidity and mortality. 
The behavioral observations (Resting or sleeping, lying at any position and sitting; locomotion; grooming; investigatory as rubbing, licking, gnawing, smelling; aggressive as biting, fighting and chasing each other) were carried out (Paul and Patrick, 2007). All rabbits were monitored from 1200 to $1400 \mathrm{~h}$ for 3 days a week to get 3 times of monitoring intervals for each group (10 minutes at each time).

\section{Statistical analysis}

Data obtained from the experiment were subjected to One-Way analysis of variance according to Snedecor and Cochran (1982), using the GLM (General Linear Model) procedures of SAS software (SAS 1996). The statistical model used was as follows:

$$
Y_{i j}=\mu+T_{i}+e_{i j} \text {, }
$$

Where $Y_{i j}$ is an observation, $\mu$ is the overall mean, $T_{i}$ is the effect of feeding program, and $\mathrm{e}_{\mathrm{ij}}$ is the experimental random error.

The variations among averages of the different experimental groups were calculated (Duncan, 1955).

\section{RESULTS AND DISCUSSION}

\section{Temperature-humidity index:}

Temperature-humidity index (THI) values ranged between 27.00 and 28.87, indicating exposure of NZW rabbits to very sever heat stress (Table 1). Using a set of two or more climatic elements is necessary to ideally measure heat stress (Daader et al., 2016). The US-National Weather Service uses the THI index to help animal producers of the expected heat severity (Hahn et al. 2009; Jimoh and Ewuola, 2016).

\section{Some growth performance traits}

There were significant variations in BW at 14 and 16 weeks of age and during 12-14 and 14-16 weeks of age for BWG (Table 2). Rabbits of T3 group showed significantly $(P<0.05)$ the heaviest averages of BW and BWG. Favorable effects were found due to changing feeding program (times and quantities) over the day on growth performance. Growing rabbits utilize feed during the coolest periods of the day during the hot weather (Ojebiyi et al., 2015). The lighter BW and BWG of the control and T1 groups might attribute to the poorer health status in comparison with the others. Tưmová et al. (2003) found similar results.

There were significant variations in $\mathrm{FC}$ at $8-10$ weeks of age during and 12-14 and 14-16 weeks of age in FCR. FCR of rabbits of T3 group was significantly improved $(P<0.05)$ as shown in Table 2 . The majority of the 
Table 2. Effect of feeding program on growth performance of New Zealand White rabbits male growing rabbits

\begin{tabular}{|c|c|c|c|c|c|c|c|c|}
\hline \multirow{2}{*}{ Traits } & \multirow{2}{*}{$\begin{array}{c}\text { Age } \\
\text { (wks) }\end{array}$} & \multicolumn{5}{|c|}{ Treatment groups } & \multirow{2}{*}{ SEM } & \multirow{2}{*}{$P$ value } \\
\hline & & $\mathbf{C}$ & $\mathbf{T}_{1}$ & $\mathbf{T}_{2}$ & $\mathbf{T}_{3}$ & $\mathbf{T}_{4}$ & & \\
\hline \multirow{6}{*}{$\begin{array}{l}\text { Body } \\
\text { weight } \\
\text { (g) }\end{array}$} & 6 & 743.5 & 727.2 & 742.1 & 725.9 & 734.8 & 4.7 & 0.674 \\
\hline & 8 & 983.2 & 983.8 & 982.2 & 987.7 & 983.9 & 6.6 & 0.999 \\
\hline & 10 & 1259.3 & 1265.0 & 1275.6 & 1279.6 & 1293.6 & 9.6 & 0.828 \\
\hline & 12 & 1636.4 & 1640.0 & 1678.2 & 1688.1 & 1707.4 & 10.4 & 0.133 \\
\hline & 14 & $1939.1^{b}$ & $1939.5^{\mathrm{b}}$ & $2004.2^{\mathrm{ab}}$ & $2031.1^{\mathrm{a}}$ & $1983.3^{\mathrm{ab}}$ & 10.3 & 0.012 \\
\hline & 16 & $2157.3^{d}$ & $2188.7^{\mathrm{cd}}$ & $2243.1^{\mathrm{bc}}$ & $2343.1^{\mathrm{a}}$ & $2270.6^{\mathrm{b}}$ & 13.1 & $<.0001$ \\
\hline \multirow{6}{*}{$\begin{array}{c}\text { Body } \\
\text { weight gain } \\
\text { (g/rabbit/day) }\end{array}$} & $6-8$ & 17.1 & 18.3 & 17.1 & 18.7 & 17.8 & 0.39 & 0.637 \\
\hline & $8-10$ & 19.7 & 20.1 & 20.9 & 20.9 & 22.1 & 0.49 & 0.599 \\
\hline & $10-12$ & 26.9 & 26.7 & 28.7 & 29.1 & 29.6 & 0.49 & 0.228 \\
\hline & $12-14$ & $21.6^{\mathrm{ab}}$ & $21.4^{\mathrm{ab}}$ & $23.3^{\mathrm{a}}$ & $24.5^{\mathrm{a}}$ & $19.7^{\mathrm{b}}$ & 0.51 & 0.026 \\
\hline & $14-16$ & $15.6^{\mathrm{c}}$ & $17.8^{\mathrm{bc}}$ & $17.1^{\mathrm{c}}$ & $22.3^{\mathrm{a}}$ & $20.5^{\mathrm{ab}}$ & 0.54 & 0.0002 \\
\hline & Mean & $20.2^{d}$ & $20.8^{c d}$ & $21.4^{\mathrm{bc}}$ & $23.1^{\mathrm{a}}$ & $21.9^{b}$ & 0.18 & $<.0001$ \\
\hline \multirow{6}{*}{$\begin{array}{c}\text { Feed } \\
\text { consumption } \\
\text { (g/rabbit/day) }\end{array}$} & $6-8$ & 60.0 & 60.6 & 60.2 & 59.9 & 59.9 & 0.28 & 0.9424 \\
\hline & $8-10$ & $69.3^{\mathrm{ab}}$ & $67.5^{\mathrm{b}}$ & $71.5^{\mathrm{a}}$ & $68.9^{\mathrm{ab}}$ & $68.5^{\mathrm{ab}}$ & 0.49 & 0.0110 \\
\hline & $10-12$ & 91.6 & 90.4 & 93.6 & 90.5 & 93.1 & 0.59 & 0.279 \\
\hline & $12-14$ & 103.2 & 102.3 & 103.7 & 103.3 & 101.6 & 0.62 & 0.832 \\
\hline & $14-16$ & 107.3 & 107.7 & 109.0 & 109.6 & 108.2 & 0.57 & 0.709 \\
\hline & Mean & 86.3 & 85.6 & 87.6 & 86.5 & 86.3 & 0.39 & 0.641 \\
\hline \multirow{6}{*}{$\begin{array}{c}\text { Feed } \\
\text { conversion ratio } \\
\text { (g feed/g gain) }\end{array}$} & $6-8$ & 3.7 & 3.4 & 3.6 & 3.3 & 3.5 & 0.08 & 0.543 \\
\hline & $8-10$ & 3.80 & 3.56 & 3.5 & 3.5 & 3.19 & 0.11 & 0.544 \\
\hline & $10-12$ & 3.44 & 3.44 & 3.3 & 3.2 & 3.22 & 0.06 & 0.542 \\
\hline & $12-14$ & $4.9^{\mathrm{ab}}$ & $5.1^{\mathrm{ab}}$ & $4.8^{\mathrm{ab}}$ & $4.4^{\mathrm{b}}$ & $5.29^{\mathrm{a}}$ & 0.11 & 0.054 \\
\hline & $14-16$ & $7.2^{\mathrm{a}}$ & $6.2^{\mathrm{ab}}$ & $6.99^{\mathrm{a}}$ & $5.1^{\mathrm{b}}$ & $5.65^{\mathrm{b}}$ & 0.20 & 0.003 \\
\hline & Mean & $4.60^{a}$ & $4.33^{\mathrm{ab}}$ & $4.40^{\mathrm{ab}}$ & $3.91^{\mathrm{c}}$ & $4.17^{\mathrm{bc}}$ & 0.05 & 0.0003 \\
\hline
\end{tabular}

${ }^{b}$ Means within each row for each division with no common superscripts are significantly different $(P \leq 0.05)$.

lowering in FC and FCR in the hot season is attributed to the decrease in maintenance needs (Morêki, 2008). In this work, FC of rabbits remains below or similar to that of the control group and FCR was improved in rabbits of T3 by $21 \%$. The similar quantities of FC might be due to that the rabbits cannot over-eat (Gidenne et al., 2012) and adapted to the restriction applied (Gidenne and Lebas 2006) and weak of feed storage capacity of their stomach (Ogbu et al., 2014). Feed restriction improves FCR (Dalle Zotte et al., 2005). Rabbits consume most of feed during 03:00-06:00, 15:00-18:00 and 18:21 h (Ogbu et $a l ., 2014)$. Rabbits fed during the different periods in this work may utilize these periods and gave similar values of FC. The resemblance in FC with the 
control group may indicate that rabbits can eat at different times a day according to the availability of the feed (Ogbu et al. 2014) and the physiological status of the rabbits (Daader et al., 2016). Diet could be consumed during $16 \mathrm{~h}$ for an $85 \% \mathrm{FC}$ and during $10 \mathrm{~h}$ for a $70 \% \mathrm{FC}$ during summer season (Bergaoui et al., 2008). Feeding growing rabbits for only $10 \mathrm{~h} \mathrm{a}$ day decreased FC by $20 \%$, while night feeding decreased FC by $10 \%$ and the daily gain to 5\% (Sena et al., 2015). Ojebiyi et al. (2015) also observed that $\mathrm{BW}$ of rabbits of night feeding exceeded those diurnally fed.

\section{Some carcass traits:}

Dressed carcass and abdominal fat percentages were significantly $(P<$ 0.05) differed (Table 3). Feeding program (times and quantities) did not impact the other carcass traits. Groups of T3 and T4 had the highest percentage of dressed carcass and the lowest abdominal fat (Table 3). When implementing alternative feeding programs, carcass traits are major elements to consider (Tůmová et al., 2006). Climate could impact carcasses in two methods; firstly, through the immediate influences on organs and muscle metabolism during heat stress and those can continue after slaughter. Secondly, the differences in management processes in reaction to risks that originate from climate change could indirectly lead to differences in the carcass (Dalle Zotte et al., 2005). The present results indicate that feeding regimes seemed not to change edible parts. Ojebiyi et al. (2015) concluded that rabbits fed nocturnally had the highest carcass percentage in comparison with animals fed ad libitum or diurnally. Dressed carcass was higher in restricted rabbits than those of the ad libitum (Tůmová et al., 2006). Abdominal fat percentage was decreased due to the length of feeding time restriction (Sena et al. 2015). Also, Peris and Abd ElLatif (2021) observed that kidney fat in restricted rabbits decreased significantly compared with rabbits fed ad libitum. Insignificant differences in carcass traits of growing rabbits were also observed by Tůmová et al. (2003) and Peris and Abd El-Latif (2021).

\section{Some blood biochemical parameters}

Non-significant variations were detected in the most of blood parameters, except in ALT and glucose concentrations (Table 4). Rabbits of T3 had significantly $(P<0.05)$ the lowest activity of ALT and the highest glucose concentration. Blood parameters are significant for estimation of the health status and the level of metabolism. The current concentrations of blood parameters were within the physiological ranges reported by Özkan et al. (2012). The present results indicate that the feeding times did not influence formation and transfer of blood proteins and protein catabolism. Blood glucose is a commensurable indicator that can be used to assess the acuteness of the 
Table 3. Effect of feeding program on dressing and edible percentages of New Zealand White rabbits male growing rabbits.

\begin{tabular}{|c|c|c|c|c|c|c|c|}
\hline \multirow{2}{*}{ Traits } & \multicolumn{5}{|c|}{ Treatment groups } & \multirow{2}{*}{ SEM } & \multirow{2}{*}{$P$ value } \\
\hline & $\mathrm{C}$ & $T_{1}$ & $\mathbf{T}_{2}$ & $\mathbf{T}_{3}$ & $T_{4}$ & & \\
\hline $\begin{array}{c}\text { Dressed } \\
\text { carcass \% }\end{array}$ & $58.69^{\mathrm{ab}}$ & $57.33^{\mathrm{b}}$ & $58.71^{\mathrm{ab}}$ & $58.86^{\mathrm{ab}}$ & $59.47^{\mathrm{a}}$ & 0.423 & 0.0365 \\
\hline Heart, \% & 0.412 & 0.402 & 0.423 & 0.404 & 0.413 & 0.001 & 0.5062 \\
\hline Liver, \% & 3.83 & 4.95 & 3.91 & 4.22 & 4.10 & 0.062 & 0.0996 \\
\hline Kidney, \% & 0.712 & 0.691 & 0.753 & 0.682 & 0.691 & 0.083 & 0.4562 \\
\hline Whole fat, \% & $3.02^{\mathrm{a}}$ & $2.98^{\mathrm{ab}}$ & $2.92^{\mathrm{ab}}$ & $2.53^{\mathrm{b}}$ & $2.84^{\mathrm{ab}}$ & 0.091 & 0.0195 \\
\hline
\end{tabular}

Table 4. Effect of feeding program on some biochemical blood parameters of New Zealand White rabbits male growing rabbits

\begin{tabular}{|c|c|c|c|c|c|c|c|}
\hline \multirow[t]{2}{*}{ Traits } & \multicolumn{5}{|c|}{ Treatment groups } & \multirow{2}{*}{ SEM } & \multirow{2}{*}{$P$ value } \\
\hline & C & $T_{1}$ & $T_{2}$ & $\mathbf{T}_{3}$ & $\mathbf{T}_{4}$ & & \\
\hline Total proteins $(\mathrm{mg} / \mathrm{dl})$ & 7.02 & 6.94 & 7.00 & 6.86 & 7.21 & 0.09 & 0.6352 \\
\hline Globulin (mg/dl) & 3.02 & 2.98 & 2.92 & 3.00 & 3.10 & 0.04 & 0.2631 \\
\hline Albumin (mg/dl) & 4.00 & 3.96 & 4.08 & 3.86 & 4.11 & 0.05 & 0.2454 \\
\hline A: $G$ ratio & 1.32 & 1.33 & 1.40 & 1.29 & 1.33 & 0.04 & 0.3462 \\
\hline AST U/I & 33.55 & 32.67 & 31.12 & 31.01 & 30.87 & 0.92 & 0.3263 \\
\hline ALT U/I & $18.32^{\mathrm{ab}}$ & $18.81^{\mathrm{a}}$ & $18.10^{\mathrm{ab}}$ & $16.19^{\mathrm{b}}$ & $16.22^{\mathrm{b}}$ & 0.36 & 0.0123 \\
\hline Glucose (mg/dl) & $16.11^{\mathrm{ab}}$ & $13.92^{b}$ & $14.33^{\mathrm{b}}$ & $16.88^{\mathrm{a}}$ & $15.80^{\mathrm{ab}}$ & 0.42 & 0.0502 \\
\hline Cortisol (ng/ml) & 12.93 & 13.11 & 11.80 & 10.73 & 11.00 & 1.11 & 0.3546 \\
\hline
\end{tabular}

rabbit's status and intestinal health (Harcourt-Brown and Harcourt-Brown, 2012). The elevation in plasma glucose concentration in the control group might be attributed to a reduction in glucose utilization in order to maintain energy in heat stress conditions (Hassan et al., 2016). Marai et al. (1999) attributed the reduction in blood plasma glucose (by $20.7 \%$ in NZW rabbits) to the remarkable mitigation of blood and body blobs or to the rise in glucose employment to make more power for higher muscular disbursement needed for the elevated respiratory action during heat stress. Nocturnal feeding showed low stress on the rabbits, whereas the cortisol concentrations were low. When animals kept under heat stress conditions, albumin was low (Marai et al., 1999). The reduction in AST and ALT activities in the existing work might be assigned to a decreased energizing of gluconeogenesis by the reduction in cortisol. Abdel-Monem et al. (2007) obtained comparable outcomes. ALT 
activity was lower while, total proteins levels were greater in rabbits fed nocturnally than those of diurnal feeding (Daader et al., 2002).

\section{Behavioral patterns, rectal temperature and health risks.}

The lowest $(P<0.05)$ value of rectal temperature was observed in rabbits of T3 (Table 5). Insignificant effects of feeding program (times and quantities) were found on behavioral patterns and health risks (\%). Also, mortality and morbidity percentages were not influenced by feeding program (data not shown). Changing feeding program significantly reduced rectal temperature especially in rabbits of T3 group, and it was a strategy to improve health status of rabbits. The elevation in rectum temperature under heat stress might be attributed to the fall of the physiological ways (Marai et al., 2001).

Table 5. Effect of feeding program on behavioral patterns, rectal temperature and health risks of male growing rabbits.

\begin{tabular}{|c|c|c|c|c|c|c|c|}
\hline \multirow[t]{2}{*}{ Traits } & \multicolumn{5}{|c|}{ Treatment groups } & \multirow{2}{*}{ SEM } & \multirow{2}{*}{$P$ value } \\
\hline & C & $T_{1}$ & $\mathbf{T}_{2}$ & $\mathbf{T}_{3}$ & $\mathbf{T}_{4}$ & & \\
\hline \multicolumn{8}{|c|}{ Behavioral patterns } \\
\hline Resting & 1.82 & 1.76 & 2.22 & 2.68 & 2.80 & 0.46 & 0.5719 \\
\hline Locomotor & 2.60 & 2.40 & 1.80 & 1.66 & 1.94 & 0.33 & 0.4366 \\
\hline Grooming & 0.80 & 0.67 & 0.65 & 0.46 & 0.28 & 0.08 & 0.3142 \\
\hline Investigatory & 0.07 & 0.06 & 0.06 & 0.02 & 0.04 & 0.01 & 0.4352 \\
\hline Agonistic & 0.00 & 0.07 & 0.08 & 0.00 & 0.00 & 0.02 & 0.1254 \\
\hline Rectal temperature & $40.45^{\mathrm{a}}$ & $40.19^{a b}$ & $39.67^{b}$ & $39.55^{\mathrm{b}}$ & $39.63^{b}$ & 0.08 & 0.0504 \\
\hline Health risk, \% & 10.22 & 11.16 & 9.45 & 5.88 & 8.36 & 1.76 & 0.3377 \\
\hline
\end{tabular}

The rise in respiration activity is concerning to the rise in ambient temperature and thus helps the rabbits to waste heat. Rabbits fed nocturnally had lower rectal temperature than those fed diurnally (Daader et al., 2002). At night, heat output decreases by $5 \%$ as compared with the day, and that reduction in heat output may outcome from low activity and resting or sleeping (Szendro et al., 2004). Melatonin decreases heat output during darkness, by dropping body temperature and adjusting heat waste (Rozenboim et al., 1998). Rabbits utilize body position as a tool to modify heat loss (Marai et al., 2004). In this investigation, rabbits of $\mathrm{T}_{3}$ group had the highest value of resting behavior and the lowest ones of locomotion, investigation and agonistic, indicating the feeding program of $25 \%$ at morning and $75 \%$ at night was more suitable for growing rabbits. The circadian difference in behaviors suggests the variations in these behavioral attributes following day time (Gidenne et al., 2012; Ogbu et al., 2014). The high health risks in the control and $\mathrm{T}_{1}$ groups 
could be due to the heat stress and to the stress of feed existence during the day. It could be suggested that, based on our findings, feeding limited feed quantities across the day and giving the main quantity during the night induced an improvement in rabbits health. Similar findings were found by Tůmová et al. (2003) and Duperray et al. (2012). Ojebiyi et al. (2015) reported insignificant differences in rectal temperature among rabbits fed ad libitum, nocturnal and diurnal.

\section{Conclusion}

There were favorable effects due to changing feeding times and quantities over the day on growth performance traits. Changing feeding times and quantities significantly reduced rectal temperature and it was a strategy to improve the health status of the rabbits. Feeding at the night is highly recommended for growing rabbits under heat stress of summer months.

Ethical Approval: All experimental procedures followed the guidelines of the Ethical committee of Assiut University.

Competing Interests: There is no conflict of interest.

\section{REFERENCES}

Abdel-Monem UM, Khalil BA, Mahrose KhM (2007). Effects of feeding times on performance of New Zealand White rabbit does. The $5^{\text {th }}$ International Congress of Rabbit Production Under Hot Climates, December 4-7, Hurghada, Egypt.

Abd El-Monem UM, Mahrose KhM, Khalil BA (2009). Effects of cage density and climatic conditions on the performance of growing rabbits. Zag. Vet. J., 37:198-208.

Abou-Kassem, D. E., Mahrose, Kh. M., Rania A. El-Samahy, Manal E.Shafi, El-Saadony, M. T., Abd El-Hack, M. E., Emam, M., ElSharnouby, M., Taha, A. E. and Ashour, E. A. (2021). Influences of dietary herbal blend and feed restriction on growth, carcass characteristics and gut microbiota of growing rabbits. Italian J. of Animal Science, 20, 1: 896-910, DOI: 10.1080/ 1828051 X. 2021. 1926348

Awad A, Fahim H, EL-Shhat A, Mahrose KM, Shazly S. (2021). Dietary Echinacea purpurea administration enhanced egg laying performance, serum lipid profile, antioxidant status and semen quality in duck breeders during summer season. J. Anim. Physiol. Anim. Nutr., DOI: 10.1111/jpn.13488. 
Bergaoui R, Kammoun M, Ouerdiane K (2008). Effects of feed restriction on the performance and carcass of growing rabbits. Proceedings of $9^{\text {th }}$ World Rabbit Congress, June 10-13, Verona, Italy, 547-550.

Daader AH, Nasr-Alla MM, Azazi IA, Attia SA, Seleem TS (2002). Amelioration of heat stressed Bauscat rabbits by feeding diurnally or nocturnally diets-containing Nigella sativa $L$. or fenugreek. The $3^{\text {rd }}$ International Conference on Rabbit Production in Hot Climates, Hurghada, Egypt, 287-300.

Daader AH, Yousef MK, Abdel-Samee AM, Abd El-Nour SA (2016). Recent trends in rabbit does reproductive management: special reference to hot regions. Proceedings of $1^{\text {th }}$ World Rabbit Congress, June 15-18, 2016, Qingdao, China, 149-166.

Dalle Zotte A, Rémignon H, Ouhayoun J (2005). Effect of feed rationing during post-weaning growth on meat quality, muscle energy metabolism and fibre properties of Biceps femoris muscle in the rabbit. Meat Sci., 70:301-306.

Duncan, D.B. (1955). Multiple ranges and multiple F-tests. Biometrics 11:142.

Duperray J, Laurent JM, Adelis R, Haberkorn F, Guyonvarch A (2012). Time feed restriction reduces digestive disorders without decreasing growth performances of growing rabbits in ERE conditions. Proceedings of $10^{\text {th }}$ World Rabbit Congress, September 3 - 6, Sharm El-Sheikh, Egypt, 663-668.

Farghly MFA, Mahrose KhM, Mahmoud GB, Ali RM, Daghash W, Metwally KA, Abougaba MSh (2020). Lighting programs as an appliance to improve growing New Zealand white rabbit's performance. Int J Biometeorol. https://doi.org/10.1007/s00484-02001906-z

Ferraz PP, Ferraz GS, Barbari M, Silva MG, Damasceno FA, Cecchin D, Castro JO (2019). Behavioural and physiological responses of rabbits. Agronomy Res., 17:704-710.

Gidenne T, Combs S, Fortun-Lamothe L (2012). Feed intake limitation strategies for the growing rabbit: effect on feeding behaviour, welfare, performance, digestive physiology and health: a review. Animal, 6:1407-1419.

Gidenne T, Lebas F (2006). Feeding behaviour in rabbits. In Feeding in domestic vertebrates. From structure to behaviour (ed. V. Bels). CABI Publishing, Wallingford, UK. 
Hahn GL, Gaughan JB, Mader TL, Eigenberg RA (2009). Thermal indices and their applications and thermal Environmental Managements. ASBE, 113-130.

Harcourt-Brown FM, Harcourt-Brown S (2012). Clinical value of blood glucose measurement in pet rabbits. Vet. Rec., 170:674.

Hassan FA, Mahrose KhM, Basyony M (2016). Effects of grape seed extract as a natural antioxidant on growth performance, carcass characteristics and antioxidant status of rabbits during heat stress. Arch Anim Nutr 70:141-154.

Jimoh OA, Ewuola OE (2016). Thermoregulatory response of exotic rabbit breeds during peak temperature humidity index of Ibadan. Trop Anim Prod Invest., 19:41-47.

Jimoh OA, Ewuola OE (2018). Thermophysiological traits in four exotic breeds of rabbit at least temperature humidity index in humid tropics. $J$ Basic Appl Zool., 79:81.

Marai IFM, Ayyat MS, Abd El-Monem UM (2001). Growth performance and reproductive traits at first parity of New Zealand White female rabbits as affected by heat stress and its alleviation under Egyptian conditions. Trop Anim Health Prod., 33:1-12.

Marai IFM, Ayyat MS, Gabr HA, Abd El-Monem UM (1999). Growth performance, some blood metabolites and carcass traits of New Zealand White broiler male rabbits as affected by heat stress and its alleviation, under Egyptian conditions. Cahiers Options Mediterranean, 41: 35-42.

Marai IFM, Haeeb AA, Gad AE (2004). Growth performance traits and the physiological background of young doe rabbits as affected by climatic conditions and lighting regime, under sub-tropical conditions of Egypt. Proceedings $8^{\text {th }}$ World Rabbit Congress, September 7-10, Puebla, Mexico, 288-297.

Morêki JC (2008). Feeding strategies in poultry in hot climate. NonRuminants Division, Department of Animal Production P/Bag 0032, Gaborone, Botswana.

Nofal RY, Toth S, Virag GY. (1995). Carcass traits of purebred and crossbred rabbits. World Rabbit Science, 3(4): 167-170.

NRC (1994). Nutrient Requirements of Poultry. $9^{\text {th }}$ revised ed. National Research Council, National Academy Press, Washington, D.C., USA.

Ogbu CC, Ani AO, Nwogwugwu $P$ (2014). Growth performance, feed preference and circadian variation in behavioural traits of rabbits reared singly and in group. J Anim Prod Adv 4:488-500. 
Ojebiyi OO, Olarinde OJ, Adepoju AA, Akinola AO, Adetutu OI (2015) Performance of rabbits on exclusive day and/ or night feeding regime in the derived Savannah zone of Nigeria. Online J Anim Feed Res., 5:4549.

Özkan C, Kaya A, Akgül Y (2012). Normal values of haematological and some biochemical parameters in serum and urine of New Zealand White rabbits. World Rabbit Sci., 20:253-259.

Paul M, Patrick B (2007). Measuring Behavior, An Introduction Guide. Updated edition, Cambridge University Press.

Peris S I., Abd El-Latif KM. (2021). Effect of feed restriction on growth performance, carcass traits, and some hematological and blood biochemical parameters in growing rabbits. Animal Biotechnology, 110.

Rozenboim I, Miara L, Wolfenson D (1998). The thermoregulatory mechanism of melatonin induced hypothermia in chicken. Am $J$ Physiol-Reg I 274:R232-R236.

SAS (1996). SAS Procedures Guide. Version 6. $12^{\text {ed }}$. SAS Institute INC. Cary, NC, USA.

Sena S, Sena L, Nikolova N, Biçoku Y (2015). The effect of restricted feeding for an extended period of time on the carcass`s fattening parameters of rabbits. Macedonian J. Anim. Sci., 5:19-23.

Snedecor, G.W. and W.G. Cochran (1982). Statistical Methods. 8th ed. Iowa State Univ., Press Ames, Iowa, USA

Szendrö ZS, Papp Z, Kustos K (2018) Effect of ambient temperature and restricted feeding on the production of rabbit does and their kits. Acta Agraria Kaposváriensis 22:1-17.

Szendro ZS, Birónémeth E, Radnai I, Metzger S, Princz Z, Gerencsér Zs (2004). The effect of daily lighting program on the performance of growing rabbits. Proceedings $8^{\text {th }}$ World Rabbit Congress, September 710, Puebla, Mexico, 1168-1171.

Tůmová E, Skřivanová V, Skřivan M (2003). Effect of restricted feeding time and quantitative restriction in growing rabbits. Arch fur Gefl 67:182-190.

Tůmová E, Zita L, Štolc L (2006). Carcass quality in restricted and ad libitum fed rabbits. Czech J Anim. Sci. , 51:214-219. 


\section{نظم التغذية يمكنها تحسين أداء النمو والحالة الفسيولوجية فى أرانب النيوزيلندي النامية فى فصل الصيف فئ في مصر الصرئ}

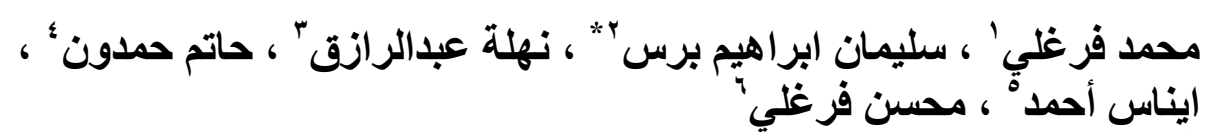

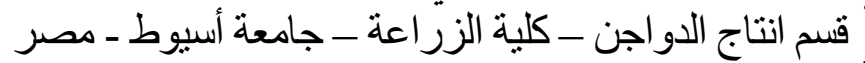

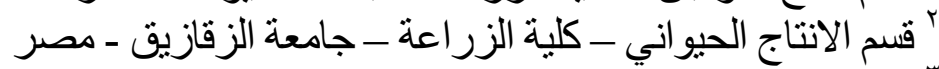

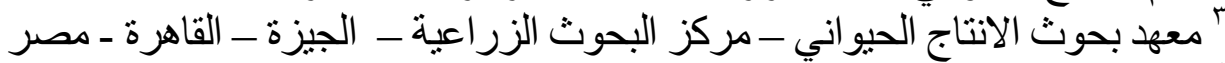

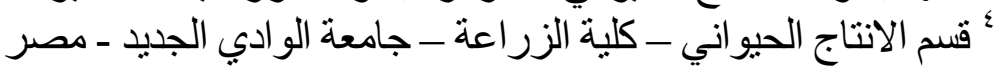

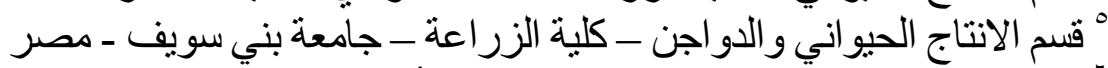

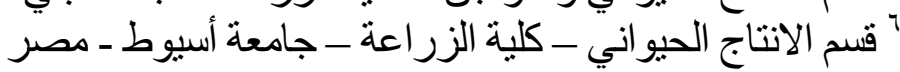

تم دراسة تأثيرات نظام التغذية (وقت وكمية) على بعض صفات النمو، المكونات

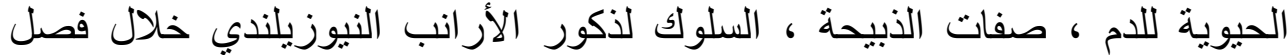

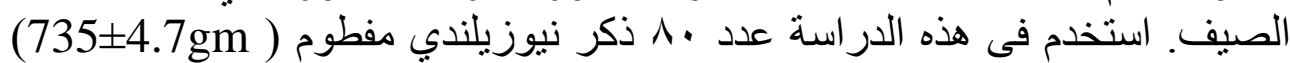

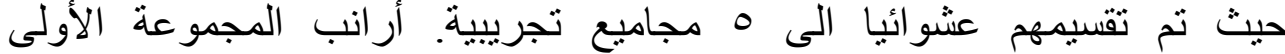

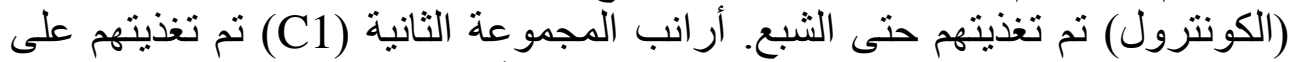

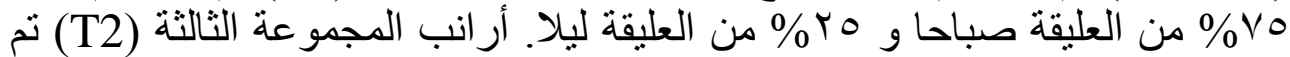

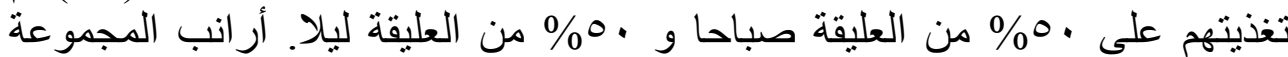

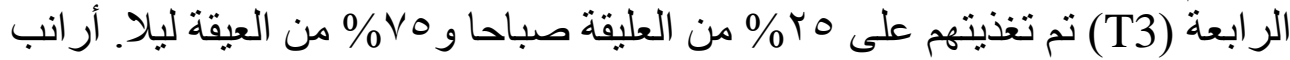

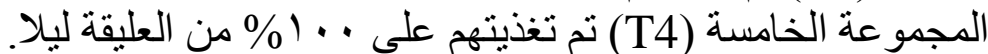

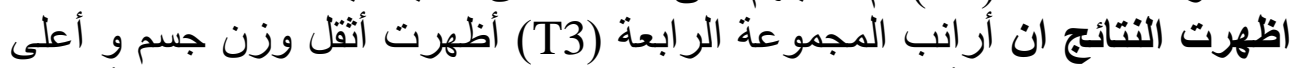

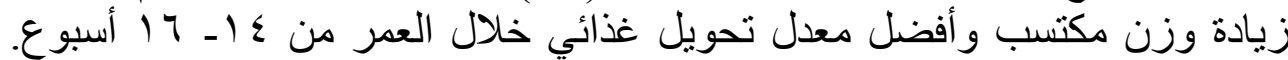

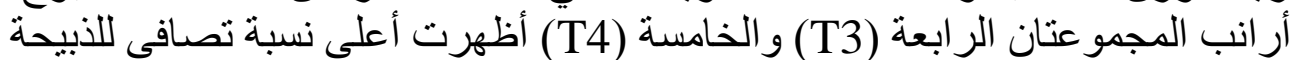

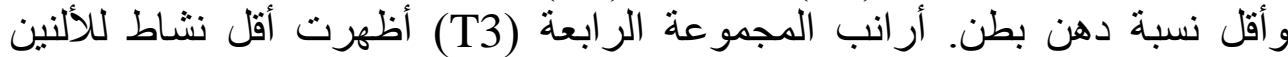

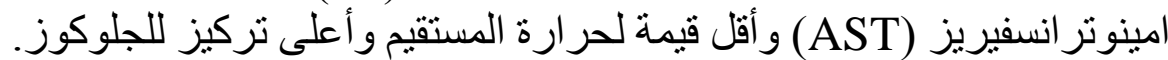

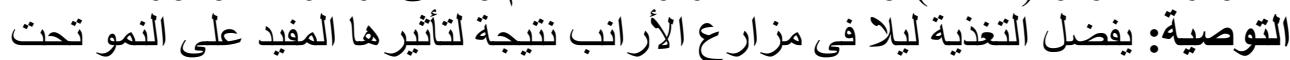

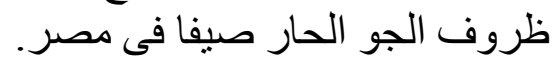

